\title{
A new monoclonal antibody (3A5) that recognises a fixative resistant epitope on tissue macrophages and monocytes
}

\author{
E H Jaspars, E Bloemena, P Bonnet, R J Scheper, E Kaiserling, C J L M Meijer
}

\begin{abstract}
Aims-To develop a monoclonal antibody specific for human macrophages in routinely processed material.

Methods-The monoclonal antibody was derived from a mouse popliteal lymph node after subcutaneous immunisation in the footpad with fragments of human spleen depleted of lymphocytes and erythrocytes.

Results-3A5 is a monoclonal antibody reactive with macrophages, monocytes, and histiocytes in routinely processed (formalin fixed, paraffin wax embedded) human tissue specimens. Unlike the well known panmacrophage marker KP1 (CD68), neither dendritic cells (interdigitating cells, Langerhans' cells, and microglia) nor myeloid, lymphoid, or epithelial cells stained with $3 A 5$.

Conclusion-As the staining pattern of $3 A 5$ is restricted, compared with other macrophage markers and the recognised epitope survives common fixation and embedding procedures, $3 A 5$ is a valuable marker for histiocytes and macrophages in routine diagnostic applications.
\end{abstract}

(F Clin Pathol 1994;47:248-252)

Macrophages are important to the immune system: they are the main effector cells in the innate immune response and are also indispensable in adaptive immunity because they process antigen, secrete soluble factors, and guide lymphocytes in their essential recirculation. ${ }^{12}$ Unlike the numerous antigens on $\mathrm{T}$ and B lymphocytes which have been identified over the past few years, specific markers for human macrophages are rare and not yet well characterised. An important reason for this is that the mononuclear phagocyte system (MPS) is morphologically and functionally diverse, and the differentiation state does not always correlate with the phenotypic appearance nor with the function of the cell.

Several antibodies have been raised against monocytes/macrophages, but most of them do not recognise all the cells or are not lineage specific. Recently, CD68 was introduced by the Fourth International Workshop on Leucocyte Differentiation Antigens as a 110 kilodalton antigen, reactive with MPS cells. ${ }^{3}$ Ever since, several anti-CD68 monoclonal antibodies have been described which differ subtly in their immunohistochemical staining patterns, possibly because of variations in gly- cosylation of the CD68 protein in different cell types. ${ }^{45}$ The functional aspects of CD68 are still unclarified, mainly due to its localisation in lysosomal granules, ${ }^{6}$ which hinders functional studies with antibodies.

Besides the need for lineage specific antibodies in fundamental research, panmacrophage markers are also of great value in diagnostic pathology. Because of the great morphological heterogeneity in macrophage cells, a clear distinction from other cells can be extremely difficult, especially when the macrophages have undergone malignant transformation. Among the expanding panel of anti-CD68 monoclonal antibodies KP1 is one of the most widely used in routine diagnostic pathology, merely because it stains cells on paraffin wax embedded tissues. ${ }^{7}$ However, besides macrophages this monoclonal antibody also reacts with myeloid cells, ${ }^{8}$ "plasmacytoid" T lymphocytes, ${ }^{9}$ and epithelial cells in certain disorders. ${ }^{1011}$

\section{Methods}

PRODUCTION OF MONOCLONAL ANTIBODIES A spleen specimen, surgically removed because of a vena lienalis thrombosis, was depleted of lymphocytes and erythrocytes by cutting and squeezing it through a nylon gauze. The remaining substance was fragmented by a Polytron blender, suspended in phosphate buffered saline (PBS), emulsified in Freund's Complete Adjuvant (1 in 1), and injected subcutaneously (three times) in the footpads of Balb/C mice (10 $\mu \mathrm{l} /$ footpad). Four days after the last injection, lymphocytes from the popliteal lymph nodes were fused with Sp20-Ag14 mouse myeloma cells, following standard techniques, as described before. ${ }^{13}$ The supernatant fluids were initially screened on cryostat sections of human spleen and tonsil for immunohistochemical reactivity with macrophages. Further testing was performed on paraffin wax embedded material. The selected hybrid (3A5) was subcloned three times.

For double staining (see below), the following monoclonal antibodies were used: the anti-CD68 KP1, commercially obtained from Dako reagents (Copenhagen, Denmark), and PG-M1, kindly provided by Dr B Falini (Perugia, Italy).

\section{CELIS AND CELL LINES}

Routine bone marrow smears taken for diagnostic purposes were obtained from the Pathology Department of Westeinde 
Hospital, The Hague, The Netherlands. The slides were air-dried and stored at $-20^{\circ} \mathrm{C}$. Before use they were fixed in acetone for 10 minutes. Peripheral blood mononuclear cells were prepared from anticoagulated blood by Ficoll-Hypaque density centrifugation. Monocytes were purified by counterflow centrifugation elutruation as described before. ${ }^{14}$

THP-1 (a monocytic leukaemia cell line), U-937 (a B cell lymphoma cell line with monocytic characteristics), K-562 (an erythroleukaemia cell line with pluripotential differentiation abilities), and HL60 (a myeloid cell line) were cultured in RPMI 1640 containing $10 \%$ fetal calf serum, supplemented with 4 $\mathrm{mM}$ glutamin, $10 \mathrm{U} / \mathrm{ml}$ penicillin, and 0.1 $\mathrm{mg} / \mathrm{ml}$ streptomycin.

Peripheral blood monocytes and cell lines were stimulated for $0.5,1$, or 2 hours in RPMI medium containing 100-500 U/ml interferon $\gamma, 10-40 \mu \mathrm{g} / \mathrm{ml}$ lipopolysaccharide (LPS), or 5-20 nM phorbol myristate acetate (PMA). Immunocytochemical staining of the cells was performed on cytospin preparations, which were air-dried, fixed in acetone, and stored at $-20^{\circ} \mathrm{C}$.

\section{FIXATION PROCEDURES}

Most of the tissues were obtained from surgical procedures in our own clinic (Surgical Department, Free University Hospital, Amsterdam, The Netherlands). Some of the specific histiocytic lesions were kindly provided by Professor H Kerl (Gratz, Switzerland) and Dr M Santucci (Florence, Italy). Part of the tissue was snap frozen and stored in liquid nitrogen. Frozen sections (4 $\mu \mathrm{m})$ were cut, mounted on poly-L-lysine coated glass slides, dried and fixed in acetone for 10 minutes before performing immunohistochemistry. Other part of the tissues were fixed in Sensofix (Sensomed, Beuningen, The Netherlands), sublimate buffered formalin or formalin, and embedded in paraffin wax. Sections $(4 \mu \mathrm{m})$ were cut and stored at $4^{\circ} \mathrm{C}$. Before immunostaining, the slides were dewaxed in xylol and rehydrated in a graded series of ethanol.

\section{IMMUNOPEROXIDASE STAINING}

For immunohistochemistry, a standard twostep immunoperoxidase staining procedure was performed as described before. ${ }^{15}$ To improve the staining results of $3 \mathrm{~A} 5$, the formalin fixed tissues were preincubated with 10 $\mathrm{mM}$ citrate buffer $(\mathrm{pH} 6)$ for 5 minutes at 720 Watts in a microwave oven. Frozen sections and material fixed in Sensofix or sublimate buffered formalin needed no additional treatment. Isotype analysis was performed using isotype specific peroxidase conjugates (Serotec, Oxford, England).

For double staining the slides were first stained with the first monoclonal antibody by the two-step immunoperoxidase procedure using 3.3 diamino benzidine tetrahydrochloride as a substrate; the second monoclonal antibody was visualised by the alkaline phosphatase method, essentially as described. ${ }^{15} 16$

\section{Results}

The hybridoma supernatant fluids were initially screened on frozen sections of human tonsil tissue and selected for specific reactivity with tissue macrophages. The selected antibody (3A5) also stained macrophages in paraffin wax embedded material and proved to be of the IgG2B subclass.

\section{IMMUNOHISTOCHEMICAL REACTIVITY OF 3A5} ON TISSUE SECTIONS

\section{Normal tissues}

In lymph nodes, tonsils, and mucosa-associated tissue (MALT), 3A5 strongly stained the starry sky macrophages in germinal centres (fig 1), but also macrophages in $\mathrm{T}$ cell areas and in the sinuses. Follicular dendritic cells (FDC) and interdigitating cells (IDC) did not stain; neither did lymphocytes, myeloid cells, and other cell types. The white pulp of the spleen showed a comparable staining pattern with the other lymphoid tissues; red pulp macrophages were also positive. Furthermore, 3A5 reacted with most macrophages and histiocytes in all other tissues investigated (table 1). Remarkably, cells from the Langerhansinterdigitating cell series and microglia showed no reactivity.

\section{Haemopoietic cells}

In peripheral blood smears monocytes showed intracytoplasmatic staining with $3 \mathrm{~A} 5$. Some reactivity was also observed within basophilic granulocytes, but no other cell types were positive (table 1). The immunocytochemical staining of peripheral blood monocytes was granular and rather weak. Expression of the 3A5 defined antigen could not be upregulated by exposing the cells to various concentrations of monocyte activating agents, like PMA, interferon $\gamma$, or LPS.

In bone marrow smears only macrophages and mast cells stained with 3A5. Megakaryocytes and myeloid cells did not, nor did other blood forming elements. Monocyte precursor cells could not be detected by the antibody.

Cell lines

Only the THP-1 monocytic line showed some

Table 1 Immunoreactivity of $3 A 5$ on normal tissues

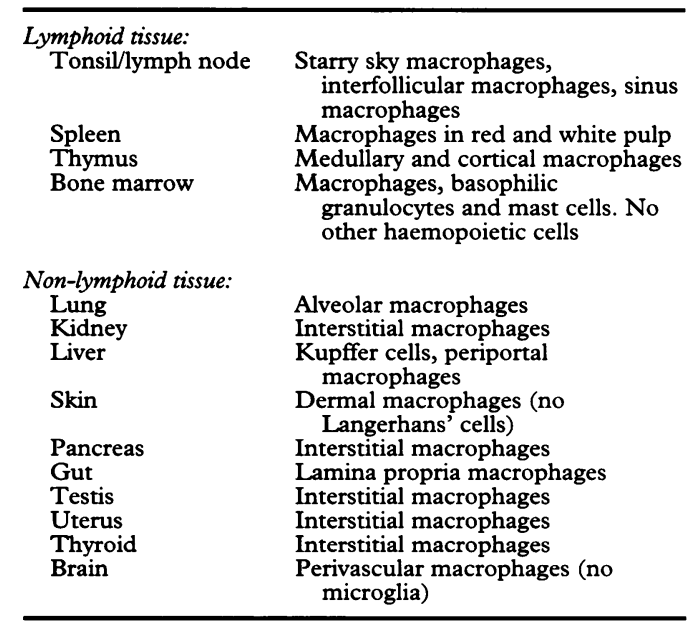




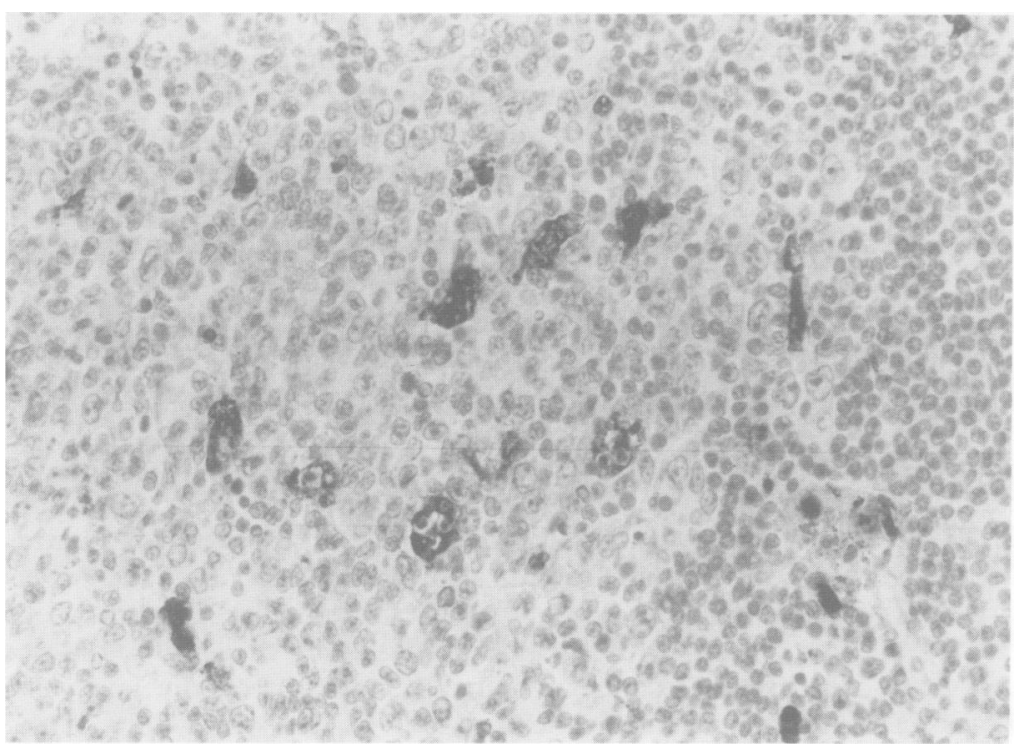

Figure 1 Starry sky macrophages in a germinal centre of a reactive lymph node, stained by $3 A 5$.

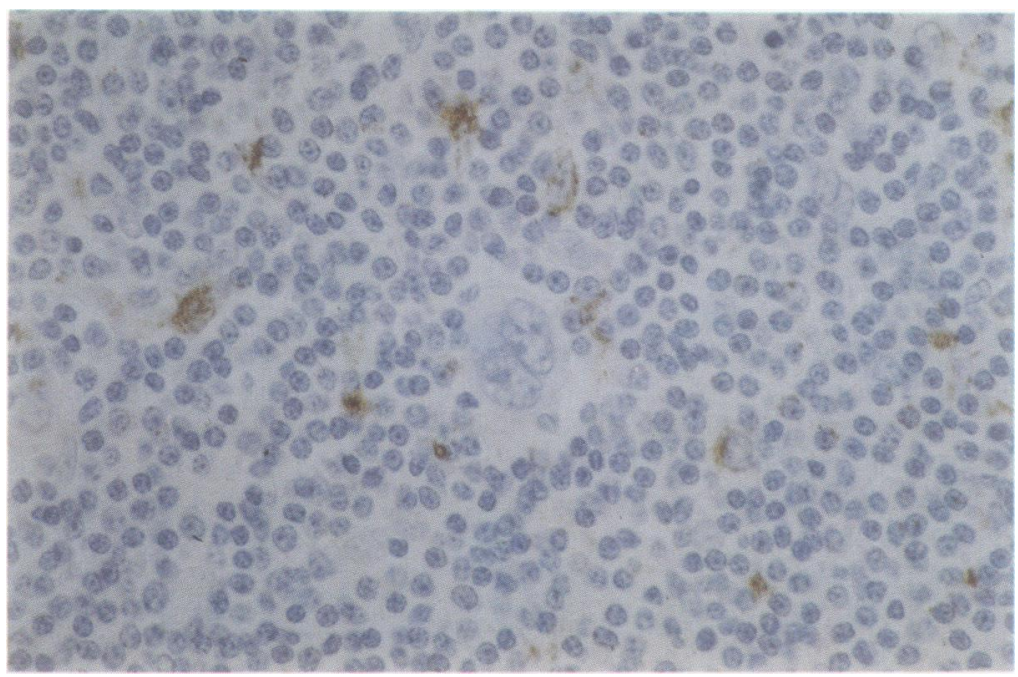

Figure 23 A5 staining of reactive histiocytic cells in a lymph node (Hodgkin's disease); the Reed-Sternberg cell (centre) remains negative.

Figure 3 Reticulohistiocytoma of the skin stained by $3 A 5$. reactivity with 3A5: the large cells stained strongly, but the smaller cells were only weakly positive or lacked the 3A5 defined antigen. The other cell lines (U937, HL60, and $\mathrm{K} 562$ ) did not react with the monoclonal antibody either unstimulated or after stimulation with several activating agents.

\section{Diseased tissues}

The distribution of the 3A5 defined antigen was investigated on a large collection of pathologically changed tissues (table 2).

Reactive lymphoid tissues - All sorts of reactive and inflamed lymph nodes were studied and most of the macrophage cells reacted. Besides the normal-looking macrophages epitheloid cells and multinucleated cells in granulomas also showed strong labelling. The dendritic cells in dermatopathic lymphadenopathy did not stain

Malignant lymphoma-In Hodgkin's disease and non-Hodgkin's lymphomas only the macrophages reacted with 3A5 (including starry sky macrophages in Burkitt-like lymphomas). Neoplastic and reactive lymphoid cells did not stain. Particular attention was paid to the $\mathrm{CD} 30$ positive cells in anaplastic T cell lymphomas: they were negative as were Reed-Sternberg cells and Hodgkin cells in the different types of Hodgkin's disease (fig 2).

Leukaemia-Leukaemic cells from biopsy specimens of patients with chronic myeloid leukaemia or hairy cell leukaemia did not stain with 3A5.

Lesions of "histiocytic origin"-3A5 stained macrophages and histiocytic cells in a variety of inflammatory conditions and lesions of histiocytic origin (fig 3). Giant cells in benign and malignant giant cell tumours also reacted

Table 2 Immunoreactivity of $3 A 5$ in pathologically changed tissue

\begin{tabular}{|c|c|}
\hline \multicolumn{2}{|c|}{ Reactivelinflamed lymph nodes } \\
\hline Follicular hyperplasia & $\begin{array}{l}\text { Follicular, interfollicular, and } \\
\text { sinus macrophages }\end{array}$ \\
\hline Sinus histiocytosis & $\begin{array}{l}\text { Follicular, interfollicular, and } \\
\text { sinus macrophages }\end{array}$ \\
\hline $\begin{array}{l}\text { Rosai Dorfmann } \\
\text { lymphadenopathy }\end{array}$ & $\begin{array}{l}\text { Follicular, interfollicular, and } \\
\text { sinus macrophages }\end{array}$ \\
\hline Toxoplasmosis & $\begin{array}{l}\text { Follicular, interfollicular, and } \\
\text { sinus macrophages and } \\
\text { epitheloid cells }\end{array}$ \\
\hline $\begin{array}{l}\text { Dermatopathic } \\
\text { lymphadenopathy }\end{array}$ & $\begin{array}{l}\text { Follicular, interfollicular, and } \\
\text { sinus macrophages (no IDC) }\end{array}$ \\
\hline \multicolumn{2}{|l|}{$\begin{array}{l}\text { Malignant lymphomas } \\
\text { Non-Hodgkin's }\end{array}$} \\
\hline $\begin{array}{l}\text { lymphomas } \\
\text { Hodgkin's lymphomas }\end{array}$ & $\begin{array}{l}\text { Macrophages, no lymphoma cells } \\
\text { Macrophages, no lymphocytes, } \\
\text { Reed-Sternberg, nor Hodgkin } \\
\text { cells }\end{array}$ \\
\hline \multicolumn{2}{|c|}{ Benign lesions of histiocytic origin } \\
\hline & $\begin{array}{l}\text { Reactive and neoplastic histiocytic } \\
\text { cells }\end{array}$ \\
\hline Granuloma annulare & Histiocytic cells \\
\hline Xanthogranuloma & Xanthoma and giant cells \\
\hline Sarcoidosis & Epitheloid and giant cells \\
\hline Reticulohistiocytoma & Histiocytic cells and giant cells \\
\hline \multicolumn{2}{|c|}{ Malignant lesions of (putative) histiocytic origin } \\
\hline Hintiontogis $\mathrm{Y}-\mathrm{z}$ & $\begin{array}{l}\text { Reactive histiocytes and } \\
\text { macrophages, no tumour cells }\end{array}$ \\
\hline \multirow{3}{*}{$\begin{array}{l}\text { Malignant fibrous } \\
\text { histiocytoma } \\
\text { Malignant giant cell } \\
\text { tumour }\end{array}$} & $\begin{array}{l}\text { Reactive histiocytes and } \\
\text { macrophages, no tumour cells }\end{array}$ \\
\hline & \\
\hline & Macrophages and giant cells \\
\hline
\end{tabular}




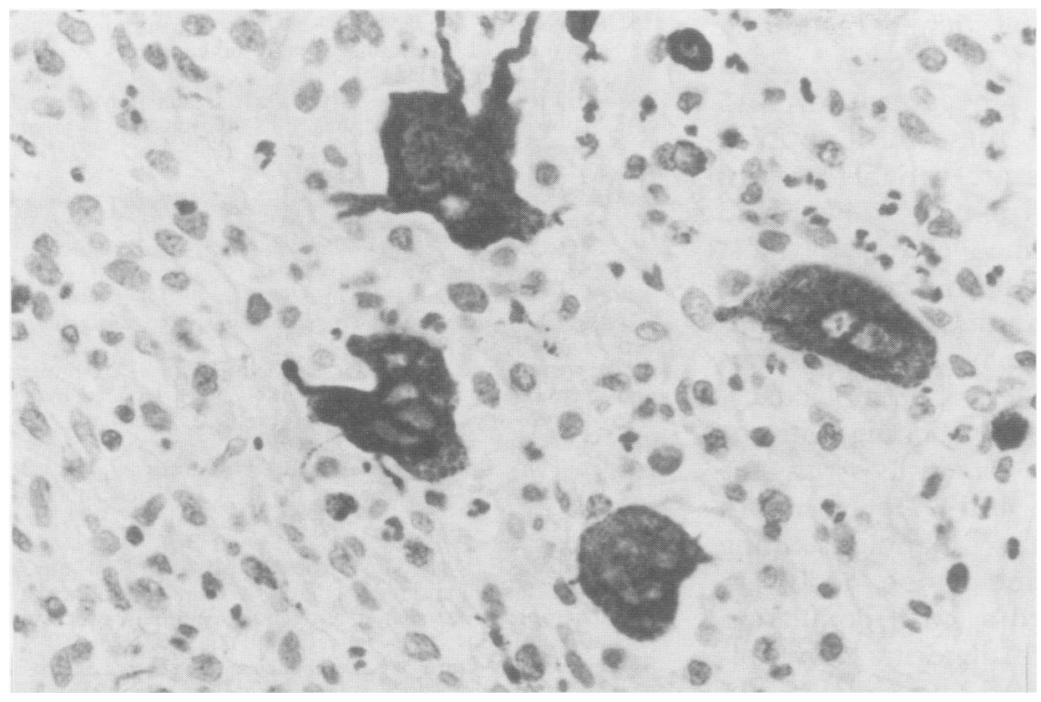

Figure 4 A giant cell tumour of the synovium showing strong reactivity with $3 A 5$ in the giant cells.

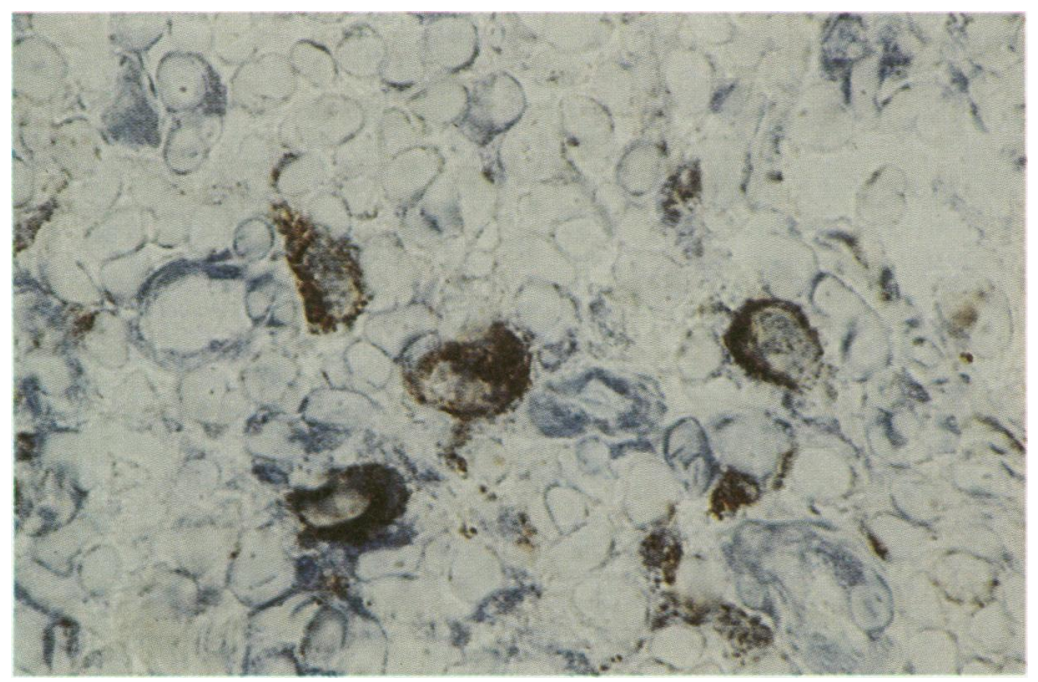

Figure 5 Immunohistochemical analysis of interfollicular cells in a lymph node reactive with $3 A 5$ (brown) and KP1 (blue). In this experiment the slides were first incubated with $3 A 5$. Note the variable double staining of some of the cells.

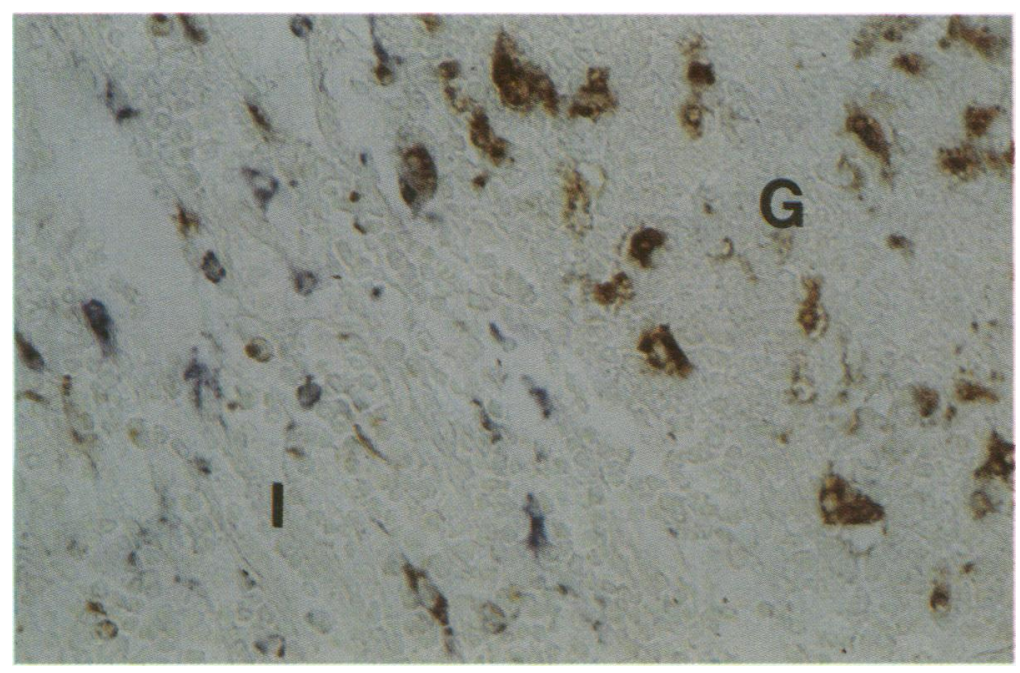

Figure 6 Immunohistochemical double staining of macrophages in a reactive lymph node, first incubated with $3 A 5$ (brown), followed by PGM-1 (blue). $G=$ germinal centre, $I=$ interfollicular area. with the monoclonal antibody (fig 4). However, the tumour cells in histiocytosis $\mathrm{X}$ and in the different variants of malignant fibrous histiocytoma lacked the antigen.

Mast cell disorders-Reactive and neoplastic mast cells in almost all cases (urticaria pigmentosa, cutaneous mastocytoma, systemic mastocytosis and malignant mastocytosis) stained, though the staining was much weaker than in macrophages and histiocytes.

Epithelial disorders-In sialadenitis, adenolymphoma of the salivary gland and hyperplastic polyps of the colon, 3A5 stained only macrophages and histiocytes. In contrast, KP1 showed reactivity with epithelial cells in these disorders, as has recently been described. ${ }^{10}$

\section{IMMUNOHISTOCHEMICAL DOUBLE STAINING}

To compare $3 \mathrm{~A} 5$ with other macrophage markers-KP1 and PG-M1-double staining was done on tonsil tissue sections. When 3A5 was added as the first monoclonal antibody, followed by KP1, the different macrophage cells showed diverse staining patterns. In starry sky macrophages very little or no KP1 reactivity remained; interfollicular macrophages showed a variable, but clearly discernible, two-coloured intracytoplasmatic staining (fig 5). In this area some cells with dendritic morphology were only positive for $\mathrm{KP} 1$. When the slides were first incubated with KP1, no further reactivity with $3 A 5$ was observed.

Double staining analysis with 3 A5 and PGM1, adding $3 A 5$ first, showed that PG-M1 also stained some cells with dendritic morphology in the paracortex which were 3A5 negative, although less than KP1 (fig 6). However, no double staining cells were detected. When PG-M1 was added first in these experiments, no further $3 \mathrm{~A} 5$ reactivity could be detected.

\section{Discussion}

3A5 is a highly specific monoclonal antibody for the macrophage lineage, as has been shown in an extensive immunohistochemical analysis of normal and diseased human tissues. Besides basophilic granulocytes and mast cells, it does not cross-react with other cell types. The detection of basophilic granulocytes and their tissue derivatives by $3 \mathrm{~A} 5$, however, is not very surprising, as it has recently been shown that these cells are very closely related to the monocytic lineage. ${ }^{17}$ According to its tissue distribution, the $3 \mathrm{~A} 5$ defined antigen is very likely to belong to the CD68 cluster. Compared with KP1, one of the most widely used anti-CD68 monoclonal antibodies, ${ }^{7}$ 3A5 shows a far more restricted staining pattern, excluding myeloid cells, dendritic cells (IDCs, Langerhans' cells, and microglia), lymphoid cells and epithelial cells. In immunohistochemical double staining experiments $3 \mathrm{~A} 5$ and $\mathrm{KP} 1$ hinder each other from binding, suggesting that the monoclonal antibodies react with partly overlapping epitopes. Because 3A5 cannot block all KP1 
reactivity in this sequential staining method, it seems that part of the KP1 antigen lacks a specific structure that is necessary for $3 \mathrm{~A} 5$ recognition. Apparently, these KP1 positive, $3 \mathrm{~A} 5$ negative molecules are variably present within the different macrophages of lymphoid tissue. As the 3A5 defined epitope is most strongly expressed in the more differentiated cells and its expression is not influenced by various activating agents, 3A5 may detect a differentiation rather than an activation molecule.

In immunohistochemical staining patterns 3A5 shows remarkable similarity with the macrophage-restricted anti-CD68 monoclonal antibody PG-M1. ${ }^{12}$ Double staining experiments on tonsil and lymph node sections, however, indicated a small population of paracortical cells with dendritic morphology, not reactive with $3 \mathrm{~A} 5$ and still PG-M1 positive. In contrast to $3 A 5, P G-M 1$ does not stain normal or reactive mast cells. ${ }^{18}$ Therefore, both monoclonal antibodies apparently do not recognise exactly the same epitope.

Like KP1 and PG-M1, the 3A5 defined epitope is resistant to routine fixation procedures, which makes it very useful for diagnostic pathologists. Moreover, 3A5 does not react with undifferentiated tumour cells other than those of histiocytic origin. The fact that histiocytosis $\mathrm{X}$ cells did not react can be explained by the fact that these tumours are derived from Langerhans' cells, which are also negative with the monoclonal antibody. No reactivity was observed in tumour cells of the different types of malignant fibrous histiocytoma. In spite of their name, however, the true origin of these tumours still remains highly controversial. ${ }^{19} 20$ Our findings support the idea that (at least part of) the malignant fibrous histiocytomas show no histiocytic differentiation.

These data led us to conclude that $3 \mathrm{~A} 5$ is not only a highly specific marker for macrophages, useful in discriminating monocytes and macrophages from other cells of the mononuclear phagocyte system, such as myeloid cells and dendritic cells, but that it may also be of great value in routine diagnostics to distinguish histiocytes from tumour cells and for typing undifferentiated malignancies.

We thank Professor H Kerl and Dr M. Santucci for providing paraffin wax sections of histiocytic disorders, Dr B Falini for the gift of PG-M1, Miss PA den Otter for expert technical assistance and Dr P van der Valk for helpful comments.
1 Unanue ER, Allen PM. The basis for the immunoregulatory role of macrophages and other accessory cells. tory role of macropha
Science $1987 ; 236: 551-7$.

2 Van den Berg TK, Breve JJP, Damoiseaux JGMC, et al. Sialoadhesin on macrophages: its identification as a lymphocyte adhesion molecule. $f$ Exp Med 1992;176: phocyte

3 Micklem KJ Cordell JL, Rigney EM, et al. A macrophageassociated antigen defined by five mAb. In: Knapp W Leucocyte Typing IV. White cell differentiation antigens. Oxford: Oxford University Press, 1989:843-6.

4 Pulford KAF, Sipos A, Cordell JL, et al. Distribution of the CD68 macrophage/myeloid associated antigen. Int Immunol 1990;2:973-80.

5 Micklem KJ, Rigney EM, Cordell JL, et al. A human macrophage-associated antigen (CD68) detected by six different monoclonal antibodies. Br $\mathcal{F}$ Haematol 1989; 73:6-11.

6 Saito N, Pulford KAF, Breton-Gorius J, et al. Ultrastructural localization of the CD68 macrophageassociated antigen in human blood neutrophils and monocytes. Am F Pathol 1991;139:1053-9.

7 Pulford KAF, Rigney EM, Micklem KJ, et al. KP1: a new monoclonal antibody that detects a monocyte/ macrophage associated antigen in routinely processed tissue sections. F Clin Pathol 1989;42:414-21.

8 Warnke RA, Pulford KAF, Pallesen G, et al. Diagnosis of myelomonocytic and macrophage neoplasms in routinely processed tissue biopsies with monoclonal routinely processed tissue biopsies with mo

9 Facchetti F, De Wolf-Peeters C, Mason DY, et al. Plasmacytoid T cells: immunohistological evidence for their monocyte/macrophage origin. Am 7 Pathol 1988; their mon $15-21$.

10 Bolz S, Ruck P, Schaumberg-Lever G, et al. Immunoelektronenmikroskopische Befunde an Zellen des Makrophagensystems mit den Monoklonalen Antikörpern KP1 (CD68) und KiM1P. Verh Disch Ges Pathol 1991;75:381.

11 Doussis IA, Gatter KC, Mason DY. CD68 reactivity of non-macrophage derived tumours in cytological specimens. F Clin Pathol 1993;46:334-6.

12 Fallini B, Flenghi L, Pileri SA, et al. PG-M1: a new monoclonal antibody directed against a fixative resistent epitope on the macrophage-restricted form of the CD68 molecule. Am f Pathol 1993;142:1359-72.

13 Kohler G, Milstein C. Continuous cultures of fused cells secreting antibodies of predicted specificity. Nature secreting antibodie

14 Figdor CG, Bont WS, Touw I, et al. Isolation of functionally different human monocytes by counterflow centrifugation elutriation. Blood 1982;60:46-53.

15 Jaspars LH, Van der Linden JC, Scheffer GL, et al. Monoclonal antibody 4C7 recognizes an endothelial basement membrane component that is selectively expressed in capillaries of lymphoid follicles. 7 Pathol 1993;170:121-8.

16 Mullink H, Henzen-Logmans SC, Alons-van Kordelaar $\mathrm{JM}$, et al. Simultaneous immunoenzyme staining of vimentin and cytokeratins with monoclonal antibodies as an aid in the differential diagnosis of malignant mesothean aid in the differential diagnosis of malignant mesothelioma from pulmonary aden Pathol) 1986;52:55-65.

17 Horny HP, Schaumburg-Lever G, Bolz S, et al. Use of monoclonal antibody KP1 for identifying normal and neoplastic human mast cells. $\mathcal{F}$ Clin Pathol 1990;43. 719-22.

18 Horny HP, Ruck P, Xiao JC, Kaiserling E. Immunoreactivity of normal and neoplastic human tissue mast cells with macrophage-associated antibodies clonal antibody PG-M1. Hum Pathol 1993;24:355-8.

19 Woods GS, Beckstead JH, Turner RR, et al. Malignant fibrous histiocytoma tumor cells resemble fibroblasts. Am 7 Surg Pathol 1986;10:323-35.

20 Roholl PJ, Kleyne J, Van Unnik JAM. Characterization of tumour cells in malignant fibrous histiocytomas and other soft tissue tumours in comparison with malignant histiocytes. II. Immunoperoxidase study on cryosta sections. Am F Pathol 1985;121:269-74. 